\title{
BURDEN OF MALARIAL PARASITEMIA; AMONG HEALTHY POPULATION OF LAHORE
}

1. MBBS, M. Phil (Microbiology) Assistant Professor of Pathology Allama Iqbal Medical College, Lahore 2. B.Sc. (Hons) Medical Lab Technology

Medical Lab Technologist

Allama Iqbal Medical College, Lahore

3. M.Sc. (Biochemistry)

M. Phil (Biotechnology)

Scientific Officer

Allama Iqbal Medical College, Lahore

4. MBBS PGR Hematology

Fatima memorial hospital Lahore

5. B.Sc. (Hons) Medical Lab

Technology

Medical Lab Technologist

Allama Iqbal Medical College Lahore

6. MBBS. M.Phil.

Prof of pathology

Akhtar Saeed Medical

College Lahore Pakistan

Correspondence Address:

Muhammad Saeed

B.Sc. (Hons) Medical Lab Technology

Medical Lab Technologist

Allama Iqbal Medical College, Lahore

mian.scientist@yahoo.com

Article received on:

28/12/2015

Accepted for publication:

02/03/2016

Received after proof reading:

$12 / 04 / 2016$

\section{Shagufta Iram ${ }^{1}$, Muhammad Saeed $^{2}$, Shahida Hussain ${ }^{3}$, Ayesha Mobeen ${ }^{4}$, Rabia Jabbar $^{5}$,} Maleeha Aslam ${ }^{6}$

ABSTRACT... Background : Hematology: $21^{\text {st }}$ century is evolutionary in the arena of medical laboratory sciences but immunological adverse reactions of blood transfusion and possible transmission of transfusion transmissible infections are still in their peak. Transmission of plasmodium via blood is significantly important because only a small fraction of infected red cells of donor blood can lead to cause malarial parasitemia in the recipient. Present study was planned to determine the frequency of Transfusion based transmissible malaria among apparently healthy blood donors. Method: This study was conducted in the department of transfusion medicine, Jinnah Hospital, Lahore. A total of 18,274 clinically healthy (volunteer and replacement) blood donors were included from 1stJanuary to 30th December 2014. Blood sample was collected through standard venipuncture method. The presence of malaria antigens was detected by the use of respective good quality immuno-chromatographic (ICT) devices. Results: Among the total 18,274 blood donors, 17,276 (94.53\%) were found healthy and safe for transfusion. The remaining 998 (5.46\%) donors were infected with any one transfusion transmissible infection and therefore not suitable for blood donations. Among the infected donors $20(0.11 \%)$ blood donors were positive for malaria.We also evaluated month wise prevalence of malaria, with highest positive rate detected in November. According to blood groups, highest prevalence was found in blood group B and the lowest was recorded in blood group $\mathrm{AB}$. Conclusion: This study provided recent scenario of asymptomatic transfusion transmissible Malaria among healthy blood donors population, therefore, it could play an important role in limiting by drawing the attention of policy makers and health department officials towards this serious health issue.

Key words: $\quad$ Malarial parasitemia, Healthy population, blood transfusions

Article Citation: Iram S, Saeed M, Hussain S, Mobeen A, Jabbar R, Aslam M. Burdan of malaria parasitemia; among healthy population of Pakistan. Professional Med J 2016;23(4):428-433. DOI: 10.17957/TPMJ/16.3224

\section{INTRODUCTION}

Globally malaria is known as world's deadliest infection particularly attacking population of tropical and sub tropical areas of the world. ${ }^{1}$ Plasmodium parasite is main causative agent for malaria and in Pakistan its most common species are plasmodium vivax and falciparum. ${ }^{2}$ Pakistan is categorized epidemiologically as a moderate malaria parasitemia endemic region with annual parasite incidence (API) rate of 1.59. ${ }^{3}$ In Pakistan almost 57,188 malarial cases per population of $179,160,100$ were reported as per report of World health organization $(\mathrm{WHO}){ }^{4}$ Post monsoon time is major transmission time period for the malaria in Pakistan. Anopheles culicifacies and A. stephensi species are susceptible to the currently using traditional insecticides. ${ }^{3}$
In life threatening emergency conditions blood transfusion is used for the management and saving patient life. Although being a life saving venture, there are some problems with the procedure if the method is not well managed, because a risk of immunological adverse reactions and possible transmission of other blood borne pathogens are always associated with blood transfusion. Malarial parasitemia is still known as one of the common transfusion transmissible infection around the world. ${ }^{5}$. In 1911 first time the term Transfusion transmitted malaria (TTM) was reported. ${ }^{6}$ Transmission of plasmodium via blood is significantly important because only a small fraction of infected red cells of donor blood can lead to cause malaria in the recipient. 
Malarial parasite has ability to survive in RBCs at low refrigerator temperatures conditions $\left(+2^{\circ} \mathrm{C}\right.$ to $+8^{\circ} \mathrm{C}$ ) and some cases in frozen blood for long duration which is responsible for the original exclusion of blood donors who represent a possible potential risk. $^{7}$ In blood MP imposes serious effects i.e., RBC destruction, hemoglobin interference, RBCs pigment disruption and conversion of haemoglobin to methaemoglobin are included. ${ }^{8}$

The major underlying risk factors responsible for the outbreak and endemicity of malarial parasitemia in Pakistan include; poor immune system of community, unpredictable transmissions approaches, low socioeconomic conditions, mass population movements in the region and crosswise international borders with Afghanistan and Iran. $^{3}$

Transfusion transmissible malaria (TTM) is particularly found in regions where blood donation is known as a commercial transaction. ${ }^{9}$ In Pakistan the trend of commercial and family replacement blood is most common method of blood donation. WHO suggested that donation of blood should be only non-remunerated and voluntary. The concept of commercial remunerated donation comes from the low incomes classes of society, living in crowded conditions, unsafe sanitary systems. ${ }^{10}$ The initials laboratory screening of TTM is the major possible step for the prevention and management of malaria in developing countries. ${ }^{11}$

The current study was therefore, conducted to assess the rate of positivity of malarial parasitemia among clinically healthy blood donors community Lahore Pakistan. This might be the first study carried out on the population of blood donors of Lahore suffering from malaria.

\section{MATERIALS AND METHODS}

This cross sectional study involved 18,274 voluntary and replacement blood donors visiting in the Blood bank Jinnah Hospital, Lahore from January to December 2014 (1 year). They age group was ranged from 17 to 60 years. Selection of donors was done as per WHO guidelines.
The donors with body weight $>45 \mathrm{~kg}$, normal blood pressure, body temperature, pulse and hemoglobin >12.5 mg/dl were included. Donors' details were noted from the consent forms kept in the blood bank record. The donor blood samples were later screened for mandatory screening tests as per WHO recommendations.

$02 \mathrm{ml}$ blood was collected as per guideline of National committee for Clinical Laboratory standard. ${ }^{12}$ The screening of all samples for presence of malaria parasite antigen was performed by using rapid immunechromatographic (ICT) technique, as described in Table I.

The technique is rapid, cheap, simple and easily interpretable. The results would displayed by development of color on the immunochromatography device. The ICT membrane is pre coated with anti Histidine rich protein 2 antibodie. Anti Histidine rich protein detect histidine present in plasmodium falciparum, anti-aldolase detect aldolase specific for plasmodium vivax and oval malaria.

\section{CONFLICT \& FUNDING}

There is no conflict of interest and no financial funding from any source.

\section{RESULTS}

The key aim of this study was to determine the frequency of TTM in health donors of Lahore. In the present study, a total of 18,274 blood donors were screened for TTI during one year. Out of total 18,274 healthy blood donors males were comprised of $18,151(99.32 \%)$ and $123(0.67 \%)$ were females. The numbers of replacement blood donors were highest $18,255(99.89 \%)$ as compared to volunteer blood donors which were only $19(0.10 \%)$.

On screening $94.53 \%(17,276 / 18274)$ donors were found safe and healthy for blood donation and only $5.46 \%(998 / 18,274)$ were infected and declared as unsafe for blood donation as per WHO recommendation (Fig: 1). 


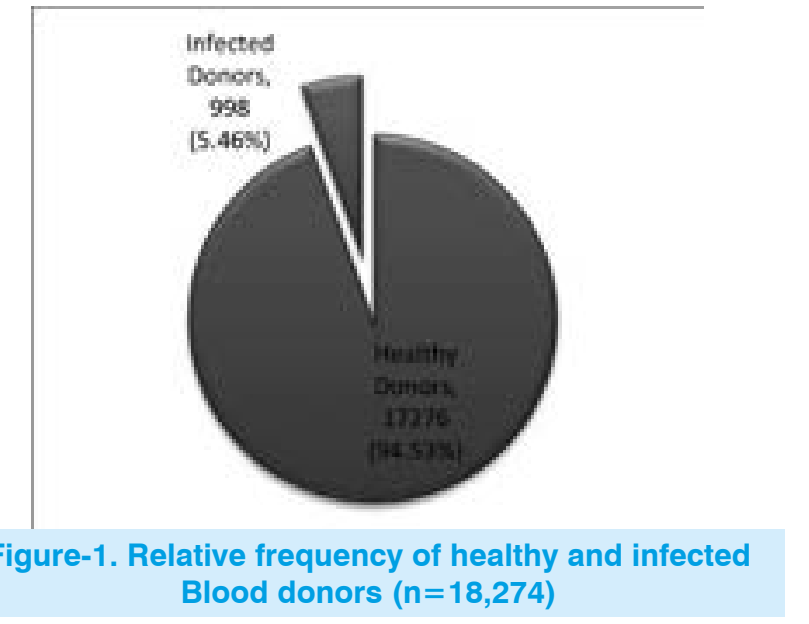

In the group of infected donors only $20(0.10 \%)$ were found positive for MP on ICT and these were comprised o 18 (0.09\%) males and 2 (0.01\%) females respectively (Table II). The low number of females observed in the present study is not a surprising point as females are naturally and culturally inhibited for blood donation due to some hormonal issues.

The donors with age group from 31-40 years showed highest positive malaria cases as compared to other groups. (Table-III). Out of 998 $(5.46 \%)$ infected blood donors, only $20(0.10 \%)$ had malarial infections as described in Fig 2.

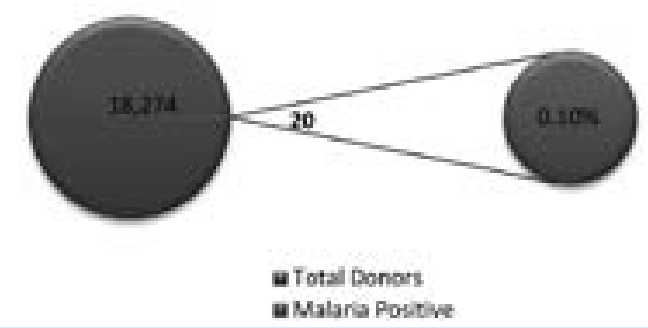

Figure-2. Relative frequency of Malaria positive blood donors $(n=18,274)$

We also evaluated the prevalence of malaria in different weather conditions of our setting. The results showed that high rate of malaria positivity were seen in the following months, September, October, November, December and January. The highest number of positive cases were found in the month of November.

We also asses the presence of malarial antigen in different blood groups of donors. The results revealed that highest prevalence of malarial parasitemia was found in the blood group $B$ and lowest in blood group $A B$ (Fig: 4). This highest rate in blood group " $\mathrm{B}$ " might be due the possibility of the "B" group was the dominant blood group type encountered during the study. Therefore, there is no significant association between malaria parasite and blood groups for TTM were found in our study.

\begin{tabular}{|c|c|c|c|}
\hline PATHOGEN & $\begin{array}{c}\text { NAME OF KIT } \\
\text { MANUFACTURER }\end{array}$ & $\begin{array}{c}\text { IDENTIFICATION } \\
\text { CRITERIA }\end{array}$ & $\begin{array}{c}\text { REFERENCE VALUE POSITIVE / NEGATIVE } \\
\text { RESULTS }\end{array}$ \\
\hline Malaria parasite & Abon & Antigen & $\begin{array}{c}\text { Colored bands on P.f and/or } \\
\text { pan line regions/no band on } \\
\text { either of these two regions }\end{array}$ \\
\hline
\end{tabular}

Table-I. Screening assays used for detection of Malaria.

\begin{tabular}{|c|c|c|c|}
\hline Gender & Total & Malaria positive & Percentage \\
\hline Male & 18151 & 18 & $0.09 \%$ \\
\hline Female & 123 & 02 & $0.01 \%$ \\
\hline Total & $\mathbf{1 8 , 2 7 4}$ & $\mathbf{2 0}$ & $\mathbf{0 . 1 0} \%$ \\
\hline
\end{tabular}

Table-II. Gender wise distribution of malarial parasitemia

\begin{tabular}{|c|c|c|c|}
\hline Age Group & Total & Malaria positive & Percentage \\
\hline $17-30$ & 7373 & 3 & $15 \%$ \\
\hline $31-40$ & 8460 & 8 & $40 \%$ \\
\hline $41-50$ & 1676 & 2 & $10 \%$ \\
\hline $51-60$ & 765 & 7 & $35 \%$ \\
\hline Total & $\mathbf{1 8 , 2 7 4}$ & $\mathbf{2 0}$ & $\mathbf{1 0 0 \%}$ \\
\hline
\end{tabular}

Table-III. Frequency of malarial parasitemia in different age group 


\begin{tabular}{|c|c|c|c|c|c|}
\hline Sr: No & Author & Year & Place & Prevalence & References \\
\hline 1 & Mahmmod et al & 2014 & Rawalpindi & $2.40 \%$ & {$[16]$} \\
\hline 2 & Waheed et al & 2012 & Islamabad & $1.20 \%$ & $17]$ \\
\hline 3 & Ali et al & 2013 & Peshawar & $0.57 \%$ & {$[15]$} \\
\hline 4 & Hussain et al & 2013 & Multan & $0.06 \%$ & {$[14]$} \\
\hline 5 & Irum et al & 2015 & Lahore & $0.10 \%$ & Current study \\
\hline
\end{tabular}

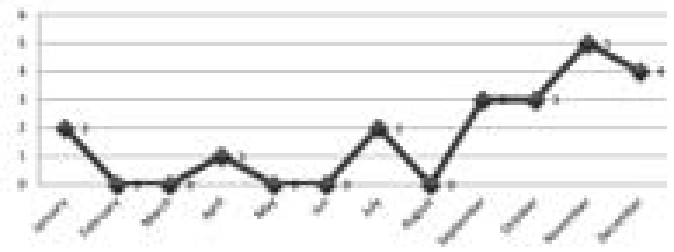

Figure-3. Month-wise incidence of MP among blood donors in 2014

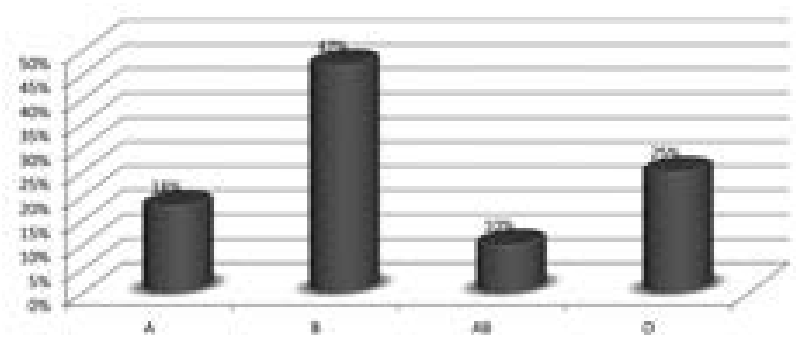

Figure-4. Blood group wise distribution of malarial parasitemia

\section{DISCUSSION}

Universally Transfusion transmissible infections (TTI) have an increased significance, due to their contribution toward the transmission and spread of infectious diseases to the healthy population. There are various other risk factors which enhance the chances of the prevalence of infectious diseases in the developing countries. The screening of blood donors can considerably reduce the possibility of transfusion transmissible infection (TTI). ${ }^{13}$

The results of our study revealed $0.10 \%$ rate of positivity for malarial parasitemia among asymptomatic community of Lahore. Which is higher as compare to (0.06\%) a study reported from Multan by Hussain et al in 2015. ${ }^{14}$ And quite lower than (0.57\%) reported by ali et al in 2013 from Peshawar. ${ }^{15}$

In a different studies Mahmood et al, and Waheed et al form Rawalpindi \& Islamabad reported malaria cases $2.4 \%, 1.2 \%$ respectively among their community donors. ${ }^{16,17}$ The results of Rawalpindi were higher as compared to present study and from Islamabad reported by Waheed et al are quite comparable to the present study. The present study revealed low frequency of malarial parasitemia cases among clinically healthy blood donors at Jinnah hospital Lahore Pakistan as compare to the previous studies. (Table-IV).

Therefore, it is need of the day to reduce burden of malarial parasitemia by implementations of WHO recommendation of appropriate blood donor selection and proper screening of blood and blood products before transfusion. Furthermore, advanced techniques such as ELISA and PCR with high specificity and sensitivity should be practiced routinely at blood transfusion services. ${ }^{18}$.

In order to minimize TTM among population, it is necessary to make an active organization that keeps all important record, history of all blood donors thought out the country and proper checking of quality of their donor selection, screening methods. The post transfusion infections in recipient must be strictly followed to improve the screening tools.

\section{CONCLUSION}

It is concluded that safety of the blood transfusion is dependent on selections of healthy blood donors from low-risk populations, implementation of blood screening for TTI and avoiding unnecessary transfusions. The well-coordinated blood transfusion services are required to maintain the quality and quaintly of these stepups at all levels.

\section{REFERENCES}

1. Ekwunife, C.A., Ozumba, N.A., Eneanya, C.I. and Nwaorgu, O.C., 2011. Malaria infection among blood 
donors in Onitsha urban, Southeast Nigeria. Sierra Leone Journal of Biomedical Research, 3(1), pp.21-26.

2. Olokoba, A.B., 2009. Viral hepatitides in voluntary blood donors in Yola, Nigeria (Doctoral dissertation, Department of Epidemiology and Community Medicine Abdulrahman MB Department of Chemical Pathology Babalola OM Department of Surgery Abdukkarim A Department of Paediatrics, University of llorin).

3. Jamison, D.T., Breman, J.G., Measham, A.R., Alleyne, G., Claeson, M., Evans, D.B., Jha, P., Mills, A. and Musgrove, $P$. eds., 2006. Disease control priorities in developing countries. World Bank Publications.

4. WHO., 2014. World malaria report 2013. World Health Organization.

5. Bruce-Chwatt, L.J., 1989. Induced and Imported Malaria: Then and Now!. In Travel Medicine (pp. 123136). Springer Berlin Heidelberg.

6. Kitchen, A.D. and Chiodini, P.L., 2006. Malaria and blood transfusion. Vox sanguinis, 90(2), pp.77-84.

7. Uneke, C.J., Ogbu, O. and Nwojiji, V., 2006. Potential risk of induced malaria by blood transfusion in South-eastern Nigeria. McGill Journal of Medicine, $9(1)$, p.8.

8. Wright, R.O., Lewander, W.J. and Woolf, A.D., 1999. Methemoglobinemia: etiology, pharmacology, and clinical management. Annals of emergency medicine, 34(5), pp.646-656.

9. Chauhan, V., Negi, R.C., Verma, B. and Thakur, S., 2009. Transfusion transmitted malaria in a non-endemic area. The Journal of the Association of Physicians of India, 57, pp.654-656.

10. Erhabor, O., Ok, O., Awah, I., Uko, K.E. and Charles, A.T., 2007. The prevalence of Plasmodia parasitaemia among donors in the Niger delta of Nigeria. Tropical doctor, 37(1), pp.32-34.
11. Mungai, M., Tegtmeier, G., Chamberland, M. and Parise, M., 2001. Transfusion-transmitted malaria in the United States from 1963 through 1999. New England Journal of Medicine, 344(26), pp.1973-1978.

12. Lima-Oliveira, G.L.O., Lippi, G., Salvagno, G.L., Montagnana, M., Picheth, G. and Guidi, G.C., 2012. Impact of the phlebotomy training based on CLSI/ NCCLS H03-A6-procedures for the collection of diagnostic blood specimens by venipuncture. Biochemia medica, 22(3), pp.342-351.

13. Arora, D., Arora, B. and Khetarpal, A., 2010. Seroprevalence of HIV, HBV, HCV and syphilis in blood donors in Southern Haryana. Indian Journal of Pathology and Microbiology, 53(2), p.308.

14. Ali, N., Ahmed, J., Ali, N., Jehan, F. and Saleem, S., 2013. Transfusion transmitted malaria in three major blood banks of Peshawar, Pakistan. African Journal of Biotechnology, 9(33).

15. Waheed, U., Khan, H. and Satti, H.S., 2012. Prevalence of transfusion transmitted infections among blood donors of a teaching hospital in Islamabad. Ann. Pak. Inst. Med. Sci, 8(4), pp.236-239.

16. Hussain, A., Mumtaz, H.M., Aslam, M.S. and Abbas, Z., 2015. Seroprevalence of transfusion based transmissible infections among clinically healthy donors in the community of Multan. Pakistan. J. Inf. Mol. Biol, 3(2), pp.47-51.

17. Mahmood, R.T., Kamran, M., Khan, M.A., Mehmood, A., Nisar, L. and Asad, M.J., 2014. Prevalence of Transfusion Transmitted Infections among Blood Donors; a Prospective Study. American Journal of Phytomedicine and Clinical Therapeutics, 2(4), pp.540543.

18. Abbas, Z., Jaffery, G. and Anwar, M.S., 2008. Seroprevalence and comparative screening of HBsAg in pediatric patients. PAKISTAN JOURNAL OF ZOOLOGY, 40(2), p.105. 


\section{PREVIOUS RELATED STUDY}

Abdul Rehman. MALARIA; THE TREND AT TEHSIL HOSPITAL LIAQTPUR (Original) Prof Med Jour 12(3) 322-326 Jul, Aug, Sep 2005.

Farooq Rahman Soomro, Juma Khan Kakar, Ghulam Murtaza Pathan. MALARIAL PARASITE; SLIDE POSITIVITY RATE AT SHIKARPUR DISTRICT SINDH PAKISTAN (Original) Prof Med Jour 16 (3) 377-379 Jul, Aug, Sep, 2009.

Farooq Rahman Soomro, Ghulam Murtaza Pathan, Doulat Bajaj, Juma Khan Kakar. MALARIAL PARASITES SPECIES; JACOBABAD DISTRICT SINDHPAKISTAN (Original) Prof Med Jour 17(3) 440-443 Jul, Aug, Sep 2010.

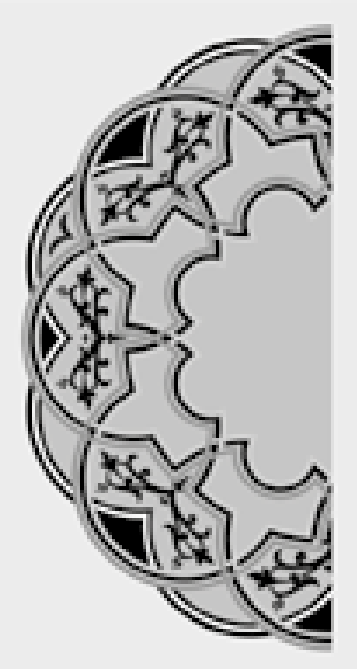

\section{"Assumption..... is the mother of all cock ups"}

Lock, Stock and Two Smoking Barrels 1998

\section{AUTHORSHIP AND CONTRIBUTION DECLARATION}

\begin{tabular}{|c|c|c|c|}
\hline Sr. \# & Author-s Full Name & Contribution to the paper & Author $=$ s Signature \\
\hline 1 & Dr. Shagufta Iram & Manuscript to the paper & \\
\hline 2 & Muhammad Saeed & $\begin{array}{l}\text { Manuscript writing, Lab } \\
\text { work }\end{array}$ & \\
\hline 3 & Shahida Hussain & $\begin{array}{l}\text { Sample Collection, Lab } \\
\text { Work, Manuscript writing }\end{array}$ & \\
\hline 4 & Dr. Ayesha Mobeen & $\begin{array}{l}\text { Manuscript writing, } \\
\text { Statistical analysis }\end{array}$ & \\
\hline 5 & Rabia Jabbar & $\begin{array}{l}\text { Sample collection, Lab } \\
\text { work }\end{array}$ & Parm \\
\hline 6 & Prof. Dr. Maleeha Aslam & Review manuscript & mateslit \\
\hline
\end{tabular}

